\title{
Dysregulated Hematopoiesis and a Progressive Neurological Disorder Induced by Expression of an Activated Form of the Human Common $\beta$ Chain in Transgenic Mice
}

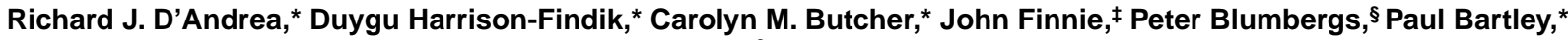 \\ Matthew McCormack, ${ }^{*}$ Karen Jones, ${ }^{\star}$ Robert Rowland, ${ }^{\S}$ Thomas J. Gonda, ${ }^{\star}$ and Mathew A. Vadas ${ }^{\star}$ \\ *The Hanson Centre for Cancer Research, Division of Human Immunology, Adelaide, 5000 South Australia, Australia; ${ }^{\star}$ Veterinary \\ Services Division, Institute of Medical and Veterinary Science, Gilles Plains, 5086 South Australia, Australia; and ${ }^{\S}$ Department of Tissue \\ Pathology, Institute of Medical and Veterinary Science, Adelaide, 5000 South Australia, Australia
}

\begin{abstract}
Previously we described activating mutations of $h \beta_{c}$, the common signaling subunit of the receptors for the hematopoietic and inflammatory cytokines, GM-CSF, IL-3, and IL-5. The activated mutant, $\mathrm{h} \beta_{\mathrm{c}} \mathrm{FI} \Delta$, is able to confer growth factor-independent proliferation on the murine myeloid cell line FDC-P1, and on primary committed myeloid progenitors. We have used this activating mutation to study the effects of chronic cytokine receptor stimulation. Transgenic mice were produced carrying the $\mathrm{h} \beta_{\mathrm{c}} \mathrm{FI} \Delta$ cDNA linked to the constitutive promoter derived from the phosphoglycerate kinase gene, $P G K-1$. Transgene expression was demonstrated in several tissues and functional activity of the mutant receptor was confirmed in hematopoietic tissues by the presence of granulocyte macrophage and macrophage colony-forming cells (CFU-GM and CFU-M) in the absence of added cytokines. All transgenic mice display a myeloproliferative disorder characterized by splenomegaly, erythrocytosis, and granulocytic and megakaryocytic hyperplasia. This disorder resembles the human disease polycythemia vera, suggesting that activating mutations in $\mathrm{h} \beta_{\mathrm{c}}$ may play a role in the pathogenesis of this myeloproliferative disorder. In addition, these transgenic mice develop a sporadic, progressive neurological disease and display bilateral, symmetrical foci of necrosis in the white matter of brain stem associated with an accumulation of macrophages. Thus, chronic $\mathrm{h} \beta_{\mathrm{c}}$ activation has the potential to contribute to pathological events in the central nervous system. (J. Clin. Invest. 1998. 102:1951-1960.) Key words: granulocyte macrophage colonystimulating factor $\bullet$ interleukin 3 - cytokine receptor • polycythemia vera $\cdot$ mutation
\end{abstract}

\section{Introduction}

IL-3, GM-CSF, and IL-5 are potent inflammatory cytokines that deliver proliferative and differentiative signals to neutro-

Address correspondence to Dr. Richard D'Andrea, Division of Human Immunology, Hanson Centre for Cancer Research, Frome Road, Adelaide, South Australia 5000, Australia. Phone: 61-8-82223480; FAX: 61-8-8232-4092; E-mail: Richard.Dandrea@imvs.sa. gov.au

Received for publication 15 April 1998 and accepted in revised form 5 October 1998.

J. Clin. Invest.

(C) The American Society for Clinical Investigation, Inc. 0021-9738/98/12/1951/10 \$2.00

Volume 102, Number 11, December 1998, 1951-1960

http://www.jci.org phils, eosinophils, monocytes, and immature multipotent progenitors via receptor complexes that comprise ligand binding $\alpha$ subunits (IL-3R $\alpha$, GMR $\alpha$, and IL-5R $\alpha$ ) and a shared signaling subunit, $\mathrm{h} \beta_{\mathrm{c}}(1-3)$. IL-3 can stimulate the proliferation and differentiation of pluripotent hematopoietic progenitor cells and lineage-committed progenitors in colony assays and also possesses macrophage-activating activity associated with $\mathrm{T}$ celldependent immune responses (4-6). The effects of GM-CSF overlap extensively with those of IL-3 although GM-CSF acts mainly on committed myeloid progenitors, stimulating proliferation and maturation and giving rise to granulocytes and monocytes (7-9). In addition GM-CSF is a potent activator of these mature cells (10). IL-3, GM-CSF, and IL-5 share the ability to induce eosinophil differentiation and activation (11-13). IL-5 activity is limited to the eosinophil lineage due to the restricted expression of its specific binding subunit IL-5R $\alpha$ (14). Whereas the activities of GM-CSF and IL-5 appear to be restricted to the myeloid lineage, there is evidence that IL-3 can increase endothelial surface expression of cell adhesion molecules, suggesting a possible nonhematopoietic role in inflammation (15).

The receptor subunits for GM-CSF, IL-3, and IL-5 are members of the cytokine receptor superfamily which is characterized by an $\sim 200$-amino acid, extracellular, cytokine receptor module $(3,16-18)$. Several studies have demonstrated that $\mathrm{h} \beta_{\mathrm{c}}$ and other members of the cytokine receptor superfamily can be activated by mutation, resulting in ligand-independent signaling (for review see reference 19). Most recently, two classes of activating mutations of $h \beta_{c}$ have been distinguished on the basis of their ability to abrogate the growth factor requirement of the murine myeloid cell line, FDC-P1, and the pro-B cell line, BaF-B03 $(19,20)$. The first $\mathrm{h} \beta_{\mathrm{c}}$ activating mutation characterized was $h \beta_{c} F I \Delta$, which arose spontaneously after retroviral infection of the IL-3/GM-CSF-dependent cell line, FDC-P1, with a $\mathrm{h} \beta_{\mathrm{c}}$ retroviral construct (21). This mutant contains an 111-bp duplication leading to a 37-amino acid duplicated segment in the membrane proximal extracellular domain. Whereas introduction of $\mathrm{h} \beta_{\mathrm{c}} \mathrm{FI} \Delta$ into FDC-P1 cells confers factor-independent growth and survival, the same is not true when this mutant is introduced into the IL-3-dependent, lymphoid cell line BaF-B03, suggesting a requirement for cell type-specific interactions $(19,20)$. The second class of activating mutation is exemplified by a mutant (V449E) in which glutamic acid is substituted for valine 449 in the transmembrane domain. Unlike $\mathrm{h} \beta_{\mathrm{c}} \mathrm{FI} \Delta$, the V449E mutant confers factor-independent growth on both FDC-P1 and BaF-B03 cells (20). This mutation is analogous to the activating mutation in the $c$-neu protooncogene (HER-2, erb-B2 receptor) and, by analogy, may lead to receptor oligomerization (reference 20 and references therein). Several other extracellular mutations 
of $\mathrm{h} \beta_{\mathrm{c}}$, including several amino acid substitutions and large deletions that truncate the extracellular domain, also lead to growth factor independence when expressed in FDC-P1, but not BaF-B03 cells $(20,22)$. The different signaling capacities of the two classes of activated mutant are also apparent when these receptors are introduced into primary cells. Infection of murine fetal liver cells with a $\mathrm{h} \beta_{\mathrm{c}} \mathrm{FI} \Delta$ retrovirus leads to factorindependent growth of granulocyte-macrophage (CFU-GM), macrophage (CFU-M), and granulocyte colonies (CFU-G) only, whereas infection with a retrovirus that carries $h \beta_{c} V 449 E$ generates colony types representative of all the myeloid/erythroid lineages (23).

With the aim of generating an animal model in which to assess the effects of chronic cytokine receptor stimulation on hematopoiesis and to determine the capacity of chronic activation to contribute to disease and oncogenesis, we have produced transgenic mice expressing the activated mutant $\mathrm{h} \beta_{\mathrm{c}} \mathrm{FI} \Delta$. Specifically, we wished to address the following questions.

Which hematopoietic lineages are effected by chronic activation of $h \beta_{c}$ ? The restricted activity of $h \beta_{\mathrm{c}} \mathrm{FI} \Delta$ in hematopoietic cell lines and primary hematopoietic progenitors suggests that hematopoietic effects will be restricted to cells of the myeloid lineage. However, recently $\mathrm{h} \beta_{\mathrm{c}}$ has been demonstrated to be phosphorylated on tyrosine in response to erythropoietin $(\text { Epo })^{1}(24)$, G-CSF (25), and thrombopoietin (26), suggesting a possible involvement in mediating the cellular response to other hematopoietic growth factors.

Does unregulated $h \beta_{c}$ activity lead to a chronic disease? Chronic inflammatory diseases may be a consequence of chronic stimulation of inflammatory cells by cytokines (27-29). The expression of a constitutively activated form of $h \beta_{c}$ in transgenic mice may induce chronic stimulation of mature myeloid cells and thus may mimic aspects of chronic inflammatory disease.

Is activated $h \beta_{c}$ an oncogene? Factor-independent FDC-P1 cells expressing activated $h \beta_{c}$, with extracellular and transmembrane mutations, have been shown to be tumorigenic by injection into syngeneic mice $(20,21)$. This assay suggests that these mutant receptors have tumorigenic potential; however, the different outcomes after infection of primary hematopoietic cells with the two classes of activated $h \beta_{c}$ mutant suggest that each could contribute differently to the aberrant cell phenotype. Expression of $\mathrm{h} \beta_{\mathrm{c}} \mathrm{FI} \Delta$ in transgenic mice will further define the oncogenic potential of this mutant.

\section{Methods}

Generation and screening of founder animals. To construct a $P G K-1 /$ $\mathrm{h} \beta_{\mathrm{c}} \mathrm{FI} \Delta$ transgene, an EcoRI-XbaI fragment encoding $\mathrm{h} \beta_{\mathrm{c}} \mathrm{FI} \Delta$ was cloned between the $P G K-1$ promoter (14) and the SV40 polyadenylation signal. The plasmid vector containing the $P G K-1$ promoter and the SV40 polyadenylation signal was provided by Prof. A. Miyajima (University of Tokyo, Tokyo, Japan). To generate transgenic animals, a 3.7-kb SspI-BamHI DNA fragment containing the mouse $P G K-1$ promoter, the $\mathrm{h} \beta_{\mathrm{c}} \mathrm{FI} \Delta \mathrm{cDNA}$, and the SV40 early region polyadenylation signal was gel purified and microinjected into CBA $\times$ C57BL $F_{1}$ hybrid mouse embryos (Bresagen Ltd., Thebarton, South

1. Abbreviations used in this paper: Epo, erythropoietin; GAPDH, glyceraldehyde-phosphate dehydrogenase; PCV, packed cell volume; $\mathrm{PV}$, polycythemia vera; SCF, stem cell factor; Tpo, thrombopoietin.
Australia, Australia). DNA was prepared from blood of 46 mice and analyzed by PCR with oligonucleotide primers (Bresatec Ltd., Thebarton, South Australia, Australia) specific for the transgene (PGK-1 sense primer: 5'ACGCTTCAAAAGCGCACGTCT3' and $\beta-10$ antisense primer: 5'ACCCGGCGAATGAGGGTC3'). For 10 positive mice, and for subsequent progeny, integration of the transgene was confirmed by Southern blot analysis of DNA prepared from mouse tail (30).

Histological and cytological examination. Mouse tissues were fixed in $10 \%$ buffered formalin and paraffin embedded. 6- $\mu \mathrm{m}$ sections were cut and stained with hematoxylin and eosin. Cytocentrifuge preparations of isolated bone marrow or spleen cells were stained with May-Grunwald Giemsa.

Peripheral blood analysis. Blood was collected at autopsy or from anaesthetized mice by orbital plexus puncture, using EDTA as an anticoagulant. Red and white blood cell and platelet counts, packed cell volume (PCV), and hemoglobin levels were obtained using an automated blood cell analyzer (Beckman Coulter Inc., Miami, FL). $P$ values were determined using the Student's $t$ test (31).

Colony assays and colony typing. Mice were killed by cervical dislocation. Bone marrow was extracted from femurs, spleens were removed, and cells were isolated by mechanical disruption. Cells were washed three times in DMEM containing 10\% FCS and plated at three different densities in A-Iscove's modified Dulbecco's medium (A-IMDM) containing 0.3\% agar (Difco, Detroit, MI) or 1.4\% $\alpha$-methylcellulose (Fluka, Buchs, Switzerland) and 25\% FCS as described (23). Colony numbers were determined in soft agar in the absence of added growth factors, or in the presence of murine GM-CSF, $100 \mathrm{U} / \mathrm{ml}$ (obtained from a crude yeast supernatant supplied by Dr. T. Wilson, Walter and Eliza Hall Institute, Melbourne, Victoria, Australia) and IL-3, $100 \mathrm{U} / \mathrm{ml}$ (produced from a baculovirus vector and supplied by Dr. A. Hapel, John Curtin School of Medical Research, Canberra, ACT, Australia). Colonies of $>50$ cells were scored microscopically after $7 \mathrm{~d}$ of culture using a grid system. In cultures where colonies were too numerous to score the total plate, a portion of known area was counted and the number of colonies obtained was multiplied to give total colony number for the whole plate. To assess colony type, individual colonies were removed from $\alpha$-methylcellulose cultures at days 7-11 of culture, air spread on glass slides as described (32), and stained with May-Grunwald-Giemsa. Colony types were determined by microscopic morphology. For quantitation of erythroid colonies (CFU-E), $5 \times 10^{5}$ spleen cells from transgenic or littermate mice were plated in MethoCult methylcellulose medium (Stem Cell Technologies, Vancouver, BC, Canada) containing A-IMDM either without added growth factor or in the presence of 2 $\mathrm{U} / \mathrm{ml}$ recombinant human Epo (Jannsen Cilag, Baar, Switzerland) and cultured at $37^{\circ} \mathrm{C}$ for $48 \mathrm{~h}$. CFU-E were stained by overlaying PBS containing $1 \mathrm{mg} / \mathrm{ml} o$-phenylenediamine plus $0.03 \% \mathrm{H}_{2} \mathrm{O}_{2}$ onto the methylcellulose cultures. Colonies consisting of eight cells or more were microscopically scored. $P$ values were determined using the Student's $t$ test (31).

Surface expression of leukocyte antigens. Bone marrow or isolated spleen cells were stained at $4^{\circ} \mathrm{C}$ with biotinylated monoclonal antibodies specific for mouse leukocyte antigens and washed, followed by incubation with a phycoerythrin-streptavidin conjugate (Beckman Coulter Inc.). Cells were then fixed and analyzed with the following antibodies: Gr-1 (33), B220 (34, 35), Ter119 (36, 37), and Thy-1-2 (38) using an Epics XL flow cytometer (Beckman Coulter Inc.).

Immunoprecipitation and Western blot analysis. Spleen cells $(2.5 \times$ $10^{8}$ ) were lysed at $4^{\circ} \mathrm{C}$ for $40 \mathrm{~min}$ in buffer containing $150 \mathrm{mM} \mathrm{NaCl}$, $10 \mathrm{mM}$ Tris- $\mathrm{HCl}, \mathrm{pH} 7.4,1 \%$ Triton $\mathrm{X}-100$, and the protease inhibitor cocktail Complete $^{\mathrm{TM}}$ (Boehringer Mannheim GmbH, Mannheim, Germany). After removal of debris by centrifugation, the lysate was immunoprecipitated using the $\mathrm{h} \beta_{\mathrm{c}}$-specific monoclonal antibody $8 \mathrm{E} 4$ (39) and protein A-Sepharose beads (Amersham Pharmacia Biotech, Uppsala, Sweden). Proteins separated by $7.5 \%$ SDS-PAGE were then transferred to nitrocellulose and detected using a second $\mathrm{h} \beta_{\mathrm{c}^{-}}$ 
specific monoclonal antibody $1 \mathrm{C} 1$ (40) and enhanced chemiluminescence (Pierce Chemical Co., Rockford, IL). Control immunoprecipitations were performed using lysate from BaF-B03 cells expressing wild-type $\mathrm{h} \beta_{\mathrm{c}}$.

RNA isolation and expression analysis. RNA was extracted using RNAzolB ${ }^{\mathrm{TM}}$ (Tel-Test Inc., Friendswood, TX), following the manufacturer's instructions, treated with 30 U RQ1-RNase I Free DNase I (Promega Corp., Madison, WI) at $37^{\circ} \mathrm{C}$ for $4 \mathrm{~h}$ to remove any contaminating genomic DNA, and resuspended in sterile, diethylpyrocarbonate-treated water. After a 5-min incubation at $65^{\circ} \mathrm{C}$, the purified RNA was incubated at $37^{\circ} \mathrm{C}$ for $2 \mathrm{~h}$ with the following reagents to generate cDNA: $1 \times$ First strand RT Buffer ${ }^{\mathrm{TM}}$ (Life Technologies Inc., Grand Island, NY), $0.01 \mathrm{M}$ DTT, $0.5 \mathrm{nM}$ dNTP cocktail, 10 U RNA Guard ${ }^{\mathrm{TM}}$ (Amersham Pharmacia Biotech), 100 pmol oligo-dT adapter primer (5'GACTCGAGTCGACATCGAT $173^{\prime}$ ), and 400 U Super Script II RNase H reverse transcriptase (Life Technologies Inc.). Control samples contained no reverse transcriptase (-RT). RNase A $(0.2 \mathrm{ng} / \mathrm{ml})$ and RNase $\mathrm{H}(2.5 \mathrm{U} / \mathrm{ml})$ were then added and samples were incubated at $37^{\circ} \mathrm{C}$ for $30 \mathrm{~min}$. To confirm integrity of cDNA, we performed PCR with a $5^{\prime}$-primer specific for the glyceraldehyde-phosphate dehydrogenase cDNA (GAPDH sense primer: 5'GGGCATCTTGGGCTACACT3') and a 3'-primer specific for the synthetic adapter sequence: (5'GACTCGAGTCGACATCG3'). cDNA $(2 \mu \mathrm{l})$ was removed and mixed with the following reagents in a final volume of $50 \mu \mathrm{l}$ : $1 \times$ PCR buffer (Perkin Elmer, Foster City, CA), $2 \mathrm{mM}$ magnesium chloride, $0.025 \mathrm{nM}$ dNTPs, $100 \mathrm{ng}$ of each primer, and $2 \mathrm{U} \mathrm{Taq}$ polymerase (Perkin Elmer). PCR was performed using the following cycling parameters: $94^{\circ} \mathrm{C} / 1 \mathrm{~min}, 60^{\circ} \mathrm{C} / 1 \mathrm{~min}$, and $72^{\circ} \mathrm{C} / 30 \mathrm{~s}$ for 25 cycles, after an initial step at $94^{\circ} \mathrm{C}$ for $3 \mathrm{~min}$. Equivalent amounts of cDNA were removed for PCR analysis with $\beta$ chain-specific primers ( $\beta 2360$ primer: 5'CCCCAGGTCACCAAGGAA3' and $\beta B$-antisense primer: 5'CCGAATTCTCAACACACCTCCCCAGG3'). PCR was performed as above but with the following cycling parameters: $94^{\circ} \mathrm{C} / 1 \mathrm{~min}, 58^{\circ} \mathrm{C} / 1$ min, and $72^{\circ} \mathrm{C} / 1 \mathrm{~min}$ for 25 cycles. PCR products were fractionated on a $2 \%$ TAE-agarose gel, transferred to Hybond-N (Amersham Pharmacia Biotech), and hybridized with ${ }^{32} \mathrm{P}$-labeled GAPDH- and $\mathrm{h} \beta_{\mathrm{c}^{-}}$ specific fragments as per the manufacturer's instructions. Probe fragments were purified with BRESACLEAN ${ }^{\mathrm{TM}}$ (Bresatec Ltd., Thebarton, South Australia, Australia) and labeled with ${ }^{32} \mathrm{P}$ using a megaprime DNA labeling kit (Amersham Pharmacia Biotech). After hybridization filters were washed twice with $2 \times$ SSC, twice in $0.1 \times \mathrm{SSC} / 0.1 \% \mathrm{SDS}$ at $65^{\circ} \mathrm{C}$, and then exposed to a phosphorimaging cassette.

\section{Results}

Generation of founder transgenic mice expressing $h \beta_{c} F I \Delta$. With the aim of analyzing the consequences of chronic stimulation via the cytokine receptor, $\mathrm{h} \beta_{\mathrm{c}}$, we have generated transgenic mice in which an activated form of the receptor $\left(\mathrm{h} \beta_{\mathrm{c}} \mathrm{FI} \Delta\right)$ (21) has been linked to a promoter fragment from the $P G K-1$ gene. PGK is a housekeeping enzyme that is expressed at moderate levels in virtually all cell types (41). From 46 pups, 10 were confirmed positive for the transgene by Southern analysis (data not shown). 7 of the 10 founder transgenic animals became moribund between 7 and $25 \mathrm{wk}$ and displayed a severe neurological disturbance. One animal which did not display neurological symptoms died at $15 \mathrm{wk}$, with evidence of hemorrhage in the chest cavity and an enlarged spleen upon autopsy. The two remaining animals died at 45 and $75 \mathrm{wk}$, during anesthesia, showing no neurological symptoms or pathology at autopsy. Median age of death for the transgenic founder population was $18 \mathrm{wk}$ compared with a normal life span of 2-3 yr for nontransgenic animals. Two founder animals that survived to mating age and displayed neurological symptoms were mated to generate transgenic lines.

Function and expression of $h \beta_{c} F I \Delta$ in transgenic animals. Expression of $\mathrm{h} \beta_{\mathrm{c}} \mathrm{FI} \Delta$ in infected murine fetal liver progenitor cells has been shown previously to generate growth factorindependent granulocyte, macrophage, and granulocyte-mac-

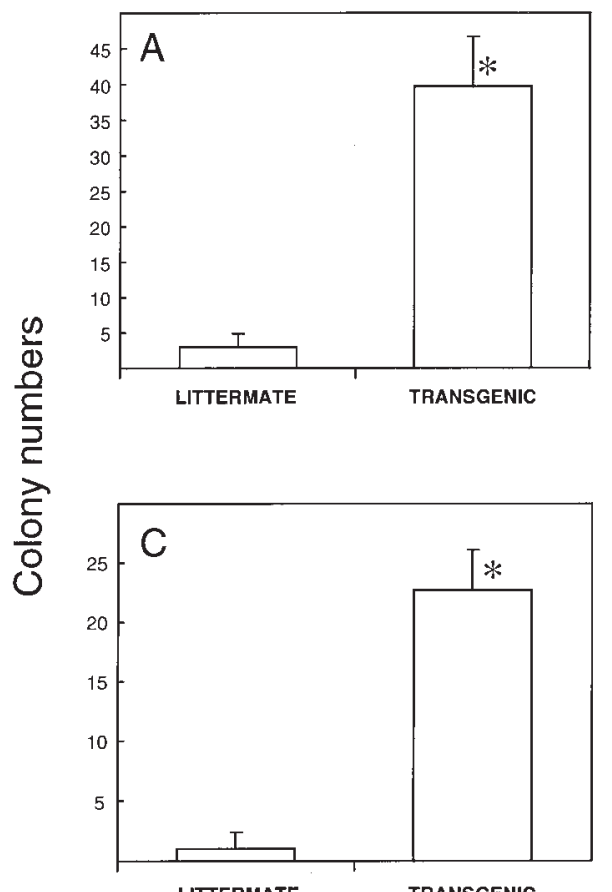

LITTERMATE

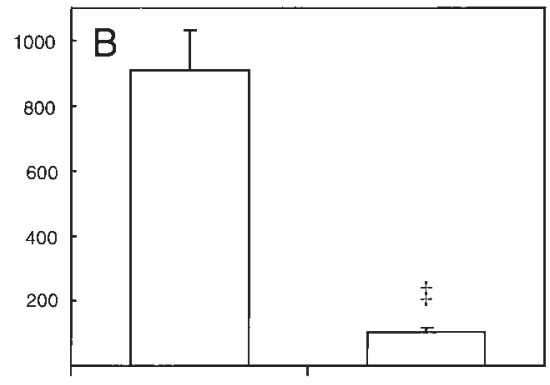

LITTERMATE TRANSGENIC

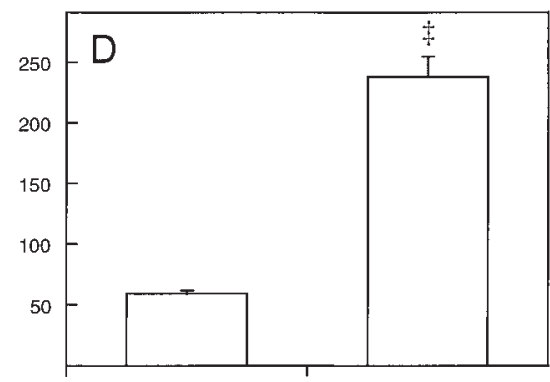

LITTERMATE
TRANSGENIC
Figure 1. Colony formation by bone marrow and spleen cells of founder $\mathrm{h} \beta_{\mathrm{c}} \mathrm{FI} \Delta$ transgenic mice and littermate controls. Cells were plated with ( $B$ and $D$ ) or without ( $A$ and $C$ ) the addition of murine GM-CSF and IL-3 in soft agar medium as described in Methods, and the resultant colonies were scored after $7 \mathrm{~d} .5 \times 10^{5}$ bone marrow cells $\left(A\right.$ and $B$ ) or $2.5 \times 10^{6}$ spleen cells ( $C$ and $D)$ from transgenic or littermate, nontransgenic mice were plated in duplicate dishes. Values represent mean \pm SEM of duplicate dishes from several experiments (transgenic bone marrow, $n=6$; control bone marrow, $n=2$; transgenic spleen, $n=3$; control spleen, $n=1$ ). Note that total cell numbers in transgenic bone marrow were not significantly different from littermates, while transgenic spleens varied in size from 1.7- to 12.2-fold larger than littermate controls. Significant numbers of colonies were obtained from the bone marrow and spleen of transgenic mice, but not littermate controls, in the absence of cytokine $(* P<$ $0.0005)$. In the presence of cytokine, colony numbers were significantly decreased in bone marrow and increased in the spleen of transgenic mice when compared with con-

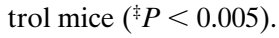




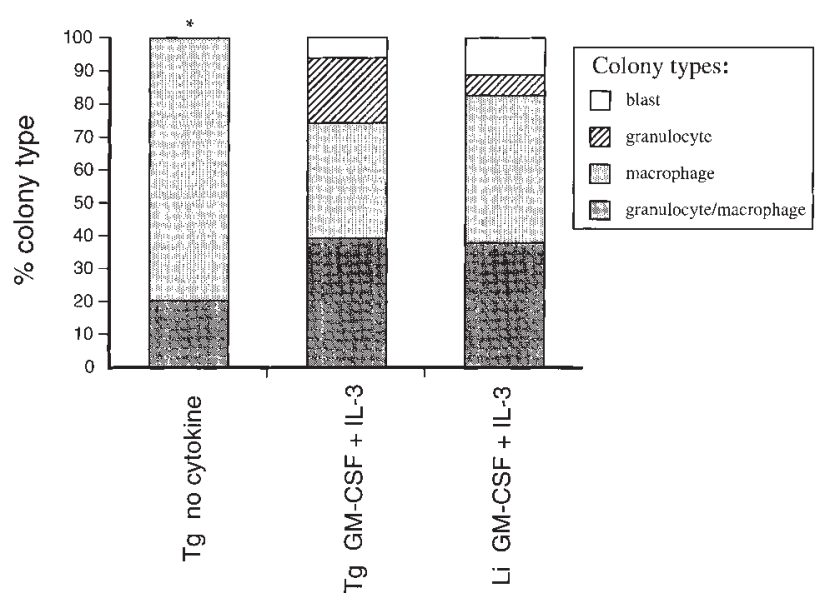

Figure 2. Typing of hematopoietic colonies from transgenic and littermate mice. Bone marrow colonies were grown in $\alpha$-methylcellulose for $7 \mathrm{~d}$ before removal and typing. Results are expressed as percentage of colony types obtained from $>50$ colonies picked from several experiments ( $n=3$ for littermate mice, $n=4$ for transgenic mice). Colony types for transgenic mice without cytokine were significantly different from colony types scored for both transgenic and control groups in the presence of cytokine $\left({ }^{*} P<0.05\right)$. $T g$, transgenic mice; $L i$, nontransgenic littermate.

rophage colony forming cells (CFU-G, CFU-M, and CFUGM) (23). Thus, we tested the growth factor requirements of these hematopoietic progenitors in transgenic mice using clonal assays. We demonstrated the growth of hematopoietic progenitors from bone marrow and spleen of transgenic mice, but not littermate controls, in the absence of added cytokines (Fig. 1, $A$ and $C$ ). The number of colonies that grew in the absence of added growth factors is relatively low compared with the number of colonies in the presence of factors. The number of cells plated in our clonal assays is large and we cannot rule out the possibility that growth in the presence of such large numbers of cells was due to an enhanced responsiveness of progenitors to growth factors produced by accessory cells. However, our results are consistent with previous results using primary murine fetal liver cells infected with retrovirus carrying $h \beta_{\mathrm{c}} \mathrm{FI} \Delta$. In this case, one quarter of infected fetal liver pro- genitors generate colonies, suggesting that this activated receptor may produce a submaximal signal resulting in reduced colony formation in vitro (23).

The numbers of GM-CSF/IL-3-dependent progenitor cells were decreased in the bone marrow of transgenic mice compared with nontransgenic littermates (Fig. $1 B$ ) and had increased in spleen (Fig. $1 \mathrm{D}$ ). The cell numbers in transgenic bone marrow were not significantly different to those of littermate controls (data not shown), suggesting that there is mobilization of progenitor cells from marrow to spleen. Given that normal mice treated with murine (m) GM-CSF or mIL-3 show a redistribution of hematopoietic progenitors through mobilization of bone marrow progenitors to peripheral hematopoietic organs $(42,43)$, this is also consistent with $\mathrm{h} \beta_{\mathrm{c}} \mathrm{FI} \Delta$ activity in hematopoietic progenitors. Bone marrow of transgenic animals yielded predominantly macrophage (CFU-M, 80\%) and granulocyte-macrophage (CFU-GM, 20\%) colonies in the absence of cytokine, whereas in the presence of GM-CSF and IL--3, granulocyte, macrophage, granulocyte-macrophage, and blast cell colonies were obtained from both transgenic mice and littermate controls (Fig. 2).

We demonstrated protein expression and confirmed that the form of $h \beta_{c}$ expressed in the transgenic animals corresponds to the activated mutant $\mathrm{h} \beta_{\mathrm{c}} \mathrm{FI} \Delta$ by immunoprecipitation and Western blotting of $\mathrm{h} \beta_{\mathrm{c}}$ from splenic extracts. Immune complexes from spleen lysates of transgenic mice, analyzed by SDS-PAGE and detected by Western blot with a second $\mathrm{h} \beta_{\mathrm{c}}$-specific monoclonal antibody, revealed a protein slightly larger than wild-type $\mathrm{h} \beta_{\mathrm{c}}$, in extracts derived from the spleens of transgenic mice (Fig. $3 a$ ). The slightly larger size of the protein compared with wild-type $h \beta_{c}$ is consistent with the 37-residue duplication present in $\mathrm{h} \beta_{\mathrm{c}} \mathrm{FI} \Delta$ (21), and demonstrates that the activated form of $h \beta_{\mathrm{c}}$ is expressed in this tissue. Semiquantitative RT-PCR analysis of several tissue samples from a transgenic mouse demonstrates that the transgene is expressed in brain, heart, kidney, and liver (Fig. $3 b$ ). We used a diagnostic SmaI digestion to confirm that the product generated by the RT-PCR procedure was derived from the transgene and not from endogenous murine $\beta_{\mathrm{c}}$ or $\beta_{\mathrm{IL}-3}$ transcripts (data not shown). The expression of the transgene in several of the tissues tested is consistent with previous transgene studies using the $P G K-1$ promoter (14). The presence of CFU-M and CFU-GM in the bone marrow and spleen of transgenic mice in

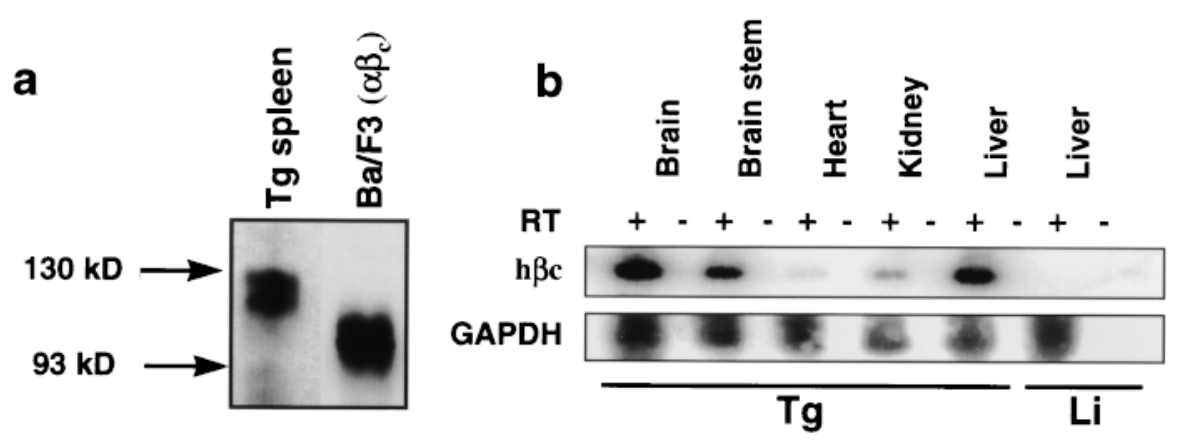

Figure 3. Expression of $\mathrm{h} \beta_{\mathrm{c}} \mathrm{FI} \Delta$ in tissues of transgenic mice. (a) Immunodetection of $\mathrm{h} \beta_{\mathrm{c}} \mathrm{FI} \Delta$ in transgenic tissues. Total cell lysates were prepared from the spleens of $\mathrm{h} \beta_{\mathrm{c}} \mathrm{FI} \Delta$ transgenic mice $\left(2.5 \times 10^{8}\right)$ and from $\mathrm{Ba} / \mathrm{F} 3$ cells $\left(2 \times 10^{6}\right.$ cells $)$ expressing GMR $\alpha$ and the wild-type form of $\mathrm{h} \beta_{\mathrm{c}}$. Immunoprecipitates were prepared using the anti-h $\beta_{\mathrm{c}}$ specific monoclonal antibody $8 \mathrm{E} 4$ and resolved by SDS-PAGE (see Methods). $\mathrm{h} \beta_{\mathrm{c}}$ was detected by Western blot analysis with a second $\mathrm{h} \beta_{\mathrm{c}}$-specific monoclonal antibody (1C1) and enhanced chemiluminescence. $\mathrm{h} \beta_{\mathrm{c}} \mathrm{FI} \Delta$ contains a 37 residue duplicated segment (21) and migrates slower than the wild-type $\mathrm{h} \beta_{\mathrm{c}}$ when fractionated by SDS-PAGE. (b) RT-PCR analysis of transgene expression. The RT-PCR protocol is described in Methods. For detection PCR products were transferred to nylon membrane and hybridized with $\mathrm{h} \beta_{\mathrm{c}}$ - or GAPDH-specific probes. Lane marked - is the PCR product of a mock cDNA (no reverse transcriptase included in the cDNA synthesis reaction). The PCR products derived from liver of a normal mouse are also shown (eleventh and twelfth lanes). The h $\beta_{\mathrm{c}}$ PCR product is digested at a diagnostic SmaI site that is not present in $\mathrm{m} \beta_{\mathrm{c}}$ or $\mathrm{m} \beta_{\mathrm{IL}-3}$ sequences. 


\begin{tabular}{|c|c|c|c|c|c|}
\hline & PCV & $\mathrm{Hgb}$ & $\operatorname{WBC}\left(\times 10^{3}\right)^{*}$ & $\operatorname{RBC}\left(\times 10^{6}\right)^{*}$ & Platelets $\left(\times 10^{3}\right)^{*}$ \\
\hline & $\%$ & $g / d l$ & & & \\
\hline Control $(n=6)$ & $51.9 \pm 1.2^{\ddagger}$ & $16.1 \pm 0.3$ & $8.93 \pm 1.42$ & $9.82 \pm 0.13^{\S}$ & $484 \pm 75$ \\
\hline Transgenic $(n=6)$ & $68.2 \pm 7.6^{\|}$ & $20.4 \pm 2.0^{\|}$ & $11.20 \pm 1.77$ & $12.52 \pm 1.1^{\|}$ & $765 \pm 171$ \\
\hline
\end{tabular}

*Values are per microliter of whole blood. ${ }^{\ddagger} \mathrm{PCV}$ range: $47.0-55.3 \%$ for littermate controls cf. $43.9-87.4 \%$ for transgenic mice. ${ }^{\S} \mathrm{RBC}$ range: $9.3-10.2$ for littermate controls cf. 8.9-15.2 $\times 10^{6} / \mu$ l for transgenic mice. ${ }^{\| V}$ alues are statistically different from control mice $(P<0.05)$.

the absence of added cytokine, and the presence of $\mathrm{h} \beta_{\mathrm{c}} \mathrm{FI} \Delta$ protein and mRNA in several tissues indicate that the transgene is expressed and functional in transgenic mice. However, we could not detect expression of $h \beta_{c}$ on bone marrow or spleen cells by flow cytometry (data not shown). We conclude from these studies that expression of $\mathrm{h} \beta_{\mathrm{c}} \mathrm{FI} \Delta$ is at a level below the detectability of flow cytometry. Therefore, the biological effects observed in this mouse model are the result of chronic low level expression of activated $\mathrm{h} \beta_{\mathrm{c}}$.

Hematological disease in transgenic animals. We noted that peripheral blood from most founder transgenic mice was more viscous than that of nontransgenic littermates. Consistent with this, blood from offspring for both transgenic lines was found to be hypererythroid as determined by analysis of PCV and red blood cell count. Hemoglobin levels were also consistently high. White blood cell counts and platelet levels were not significantly different between transgenic and control animals (Table I).

Histological analysis detected abnormalities in bone marrow and spleen of transgenic animals with and without the neurological disturbance. In vertebral bone marrow sections we observed granulocytic and megakaryocytic hyperplasia and vascular congestion with mature red blood cells (data not shown). All transgenic founders and offspring examined $(n=$ 8 ) were found to have splenomegaly (mean 5.5-fold \pm 1.2 SEM; range 1.7-12.2 $\times$ littermate control). Splenic histology revealed expanded red pulp with increased numbers of megakaryocytes in transgenic mice (Fig. 4).

Differential counts of cells isolated from bone marrow and spleen for progeny of the two transgenic founders indicated that in spleen of transgenic mice erythroid and myeloid precursors and mature granulocytes were markedly increased, whereas in bone marrow only the immature myeloid cells and granulocyte populations were expanded (Table II). Monocyte cell numbers in both bone marrow and spleen were unaltered in transgenic mice. Lymphocyte numbers in transgenic bone marrow were markedly decreased. A similar decrease in bone marrow lymphocytes, observed when transgenic mice expressing $h G M R \alpha$ and $h \beta_{c}$ were treated with hGM-CSF for $1 \mathrm{wk}$, is believed to be due to a block in T cell maturation (44) and it is likely that constitutive signaling, via $\mathrm{h} \beta_{\mathrm{c}} \mathrm{FI} \Delta$, during $\mathrm{T}$ cell development inhibits thymic precursor maturation via a similar mechanism. Total lymphocyte numbers in spleen were unaltered when splenic enlargement was considered (data not shown). Eosinophil numbers were variable among founder transgenic mice. Whereas two founders had markedly increased eosinophils (27 and 29\%) in bone marrow preparations, other founders were within the normal range $(<5 \%$, data not shown). Changes in cell numbers were also analyzed by staining cells from bone marrow and spleen with murine leukocyte antigen markers (Table III). The increased numbers of mature granulocytes in bone marrow and spleen are mirrored by a marked increase in Gr-1 staining. Decreased staining of the B cell marker, B220, and the erythroid-specific antigen, Ter119, in bone marrow is probably indicative of an overall reduction in other cell types due to granulocytic hyperplasia. Ter119 also confirmed that the number of cells derived from the erythroid lineage was markedly increased in spleen consistent with increased splenic erythropoiesis.

To investigate further the erythroid phenotype in transgenic mice we have examined the number and growth factor requirement of erythroid progenitors in spleen using a CFU-E assay. This assay confirmed that the increase in splenic erythropoiesis as the number of CFU-E in transgenic spleen in the presence of Epo had increased 20-fold compared with spleen from a littermate control (Table IV). Furthermore, we demon-

Table II. Differential Counts

\begin{tabular}{|c|c|c|c|c|c|c|c|}
\hline & & & Erythroblasts & Myeloid progenitors & Granulocytes & Monocytes & Lymphocytes \\
\hline \multirow[t]{4}{*}{ Bone marrow } & Line $30 *$ & $\mathrm{Tg}^{\ddagger}$ & $23 \pm 15^{\S}$ & $29 \pm 1$ & $47 \pm 11$ & $0.5 \pm 0.7$ & $2 \pm 2.8$ \\
\hline & & $\mathrm{Li}$ & $24 \pm 18$ & $15 \pm 5$ & $29 \pm 2$ & $1.5 \pm 0.7$ & $32 \pm 10$ \\
\hline & Line 7 & $\mathrm{Tg}$ & $7 \pm 1$ & $19 \pm 1$ & $69 \pm 4$ & $2.5 \pm 0.7$ & $3 \pm 1.4$ \\
\hline & & $\mathrm{Li}$ & $17 \pm 1$ & $14 \pm 5$ & $36 \pm 5$ & $5 \pm 3$ & $32 \pm 4$ \\
\hline \multirow[t]{2}{*}{ Spleen } & Line 30 & $\mathrm{Tg}$ & $26 \pm 0$ & $15 \pm 3$ & $8 \pm 2$ & $0.5 \pm 0.7$ & $50 \pm 6$ \\
\hline & & $\mathrm{Li}$ & $3 \pm 1$ & $0.5 \pm 0.7$ & $0.5 \pm 0.7$ & $1 \pm 1.4$ & $95 \pm 4$ \\
\hline
\end{tabular}

* Line 30 and line 7 represent two independent transgenic lines. ${ }^{\ddagger} T g$, transgenic mice; Li, nontransgenic littermate controls. ${ }^{\S}$ Mean percent types \pm SD for two mice where 200 cells were scored per cytospin preparation. 

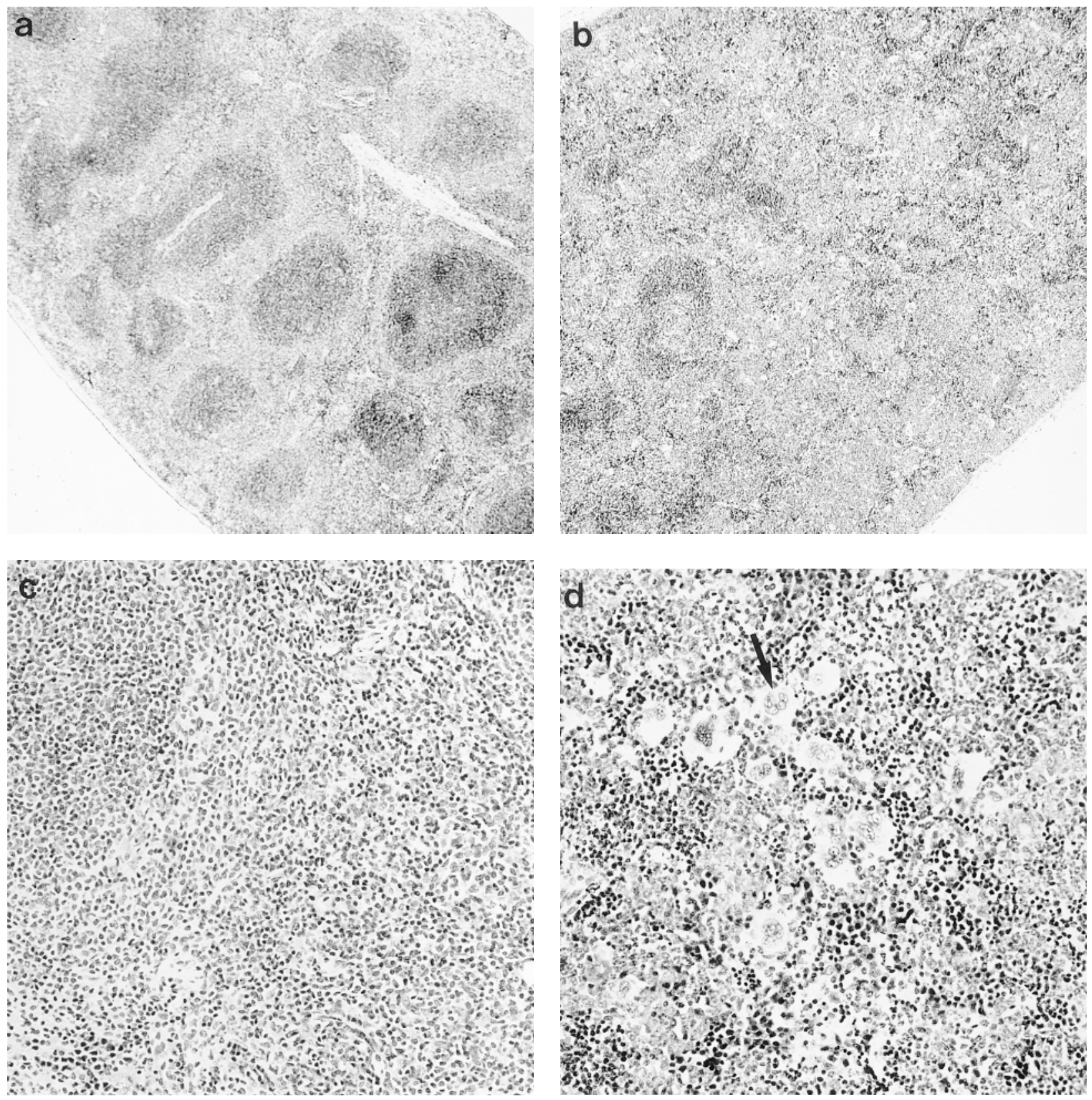

Figure 4. Spleen pathology of $\mathrm{h} \beta_{\mathrm{c}} \mathrm{FI} \Delta$ transgenic mice. Representative photomicrographs of sections from paraffin-embedded spleen of transgenic and littermate mice. (a) Spleen from nontransgenic littermate $(\times 40)$. (b) Spleen from transgenic mouse showing expanded red pulp and loss of lymphoid follicle structure $(\times 40)$. $(c)$ Red pulp from nontransgenic spleen $(\times 200)$. $(d)$ Red pulp in transgenic spleen $(\times 200)$ shows increased numbers of megakaryocytes (arrow).

strated the growth of CFU-E in spleen of transgenic mice, but not littermate controls, in the absence of added Epo. Again the number of colonies without cytokine was significantly lower than the number observed in the presence of Epo, suggesting that the signal from the activated receptor does not equal the maximal response obtained in the presence of Epo.

Neurological disease in transgenic animals. 7 of the 10 founder transgenic mice exhibited a severe neurological disturbance characterized by head tilting, circling, ataxia, and, occasionally, retropulsion. Transgenic offspring derived from both transgenic lines display a sporadic neurological disorder from 5 wk of age, although this phenotype is not completely pene- trant. The neurological symptoms in transgenic progeny are similar or identical to those observed in the founder animals. Five transgenic mice exhibiting neurological symptoms were necropsied for pathological analysis. There were no macroscopic abnormalities detected in serial coronal sections of brains cut at $1-\mathrm{mm}$ intervals. Microscopically, bilaterally symmetrical malacic foci consistently confined to the subpial region of the lateral pons and middle cerebellar peduncles were found in all animals displaying neurological symptoms but not in transgenic animals showing normal behavior. These necrotic areas (Fig. $5 a$ ), either ovoid and well-circumscribed or more irregular in outline, were largely comprised of polygonal cells 
Table III. Surface Antigen Expression

\begin{tabular}{llcccc}
\hline \multirow{2}{*}{ Bone marrow } & & GR1 & Ter119 & B220 & Thy1 \\
& Tg* & $64^{\ddagger}$ & 15 & 28 & 17 \\
\multirow{3}{*}{ Spleen } & $\mathrm{Li}$ & 39 & 20 & 47 & 15 \\
& $\mathrm{Tg}$ & 7 & 29 & 19 & 11 \\
& $\mathrm{Li}$ & 3 & 6 & 42 & 35 \\
\hline
\end{tabular}

$* T g$, transgenic mice; $L i$, nontransgenic littermate controls. ${ }^{*}$ Values are percent cells expressing the antigen from one experiment representative of three.

with generally uniform (but occasionally large and hyperchromatic) nuclei with distinct nucleoli or chromatin clumps. Their cytoplasm was frequently foamy and vacuolated (Fig. $5 b$ ) or, less commonly, granular and an occasional cell was observed in mitosis. These cells were identified morphologically as macrophages. A few multinucleated giant cells were found in some necrotic foci with gliosis and, occasionally, peripherally disposed lymphocytes. Amyloid-precursor protein-positive (45) swollen axons were occasionally present but digestion chambers (Fig. $5 c$ ), containing axonal debris and sometimes myelophages with pyknotic nuclei, were more common.

The neurological symptoms displayed by the $\mathrm{h} \beta_{\mathrm{c}} \mathrm{FI} \Delta$ transgenic mice are similar to those described for transgenic mice producing low levels of IL-3 from an astrocyte-specific GFAPIL-3 fusion gene (46). These GFAP-IL-3 mice exhibit focal
Table IV. Spleen CFU-E

\begin{tabular}{lcc}
\hline & Transgenic & Littermate \\
\hline Nil & $88 \pm 18^{*}$ & $0 \pm 0$ \\
Epo & $285 \pm 45$ & $13 \pm 4.2$
\end{tabular}

*Values are mean colony numbers \pm SD for duplicate dishes.

white matter lesions in which there is extensive primary demyelination and remyelination in association with large numbers of proliferating and activated foamy macrophage cells in cerebellum and brain stem. However, pathological examination of several lesions, in affected $\mathrm{h} \beta_{\mathrm{c}} \mathrm{FI} \Delta$ mice, failed to reveal evidence of primary demyelination. In all mice examined, pathology was consistent with symmetrical bilateral foci of necrosis in the white matter of brain stem. Thus, the underlying pathogenesis of the two transgenic models appears to be different. Detailed characterization of the cerebellar lesions in the $h \beta_{c-}$ FI $\Delta$ transgenic mice is currently underway and will be the basis of a separate study.

\section{Discussion}

The discovery of activated mutations of $h \beta_{c}$ (for review see reference 19) gave the opportunity to investigate the consequences of chronic stimulation of this receptor which normally conveys signals in response to GM-CSF, IL-3, and IL-5. We have generated transgenic mice expressing the constitutively
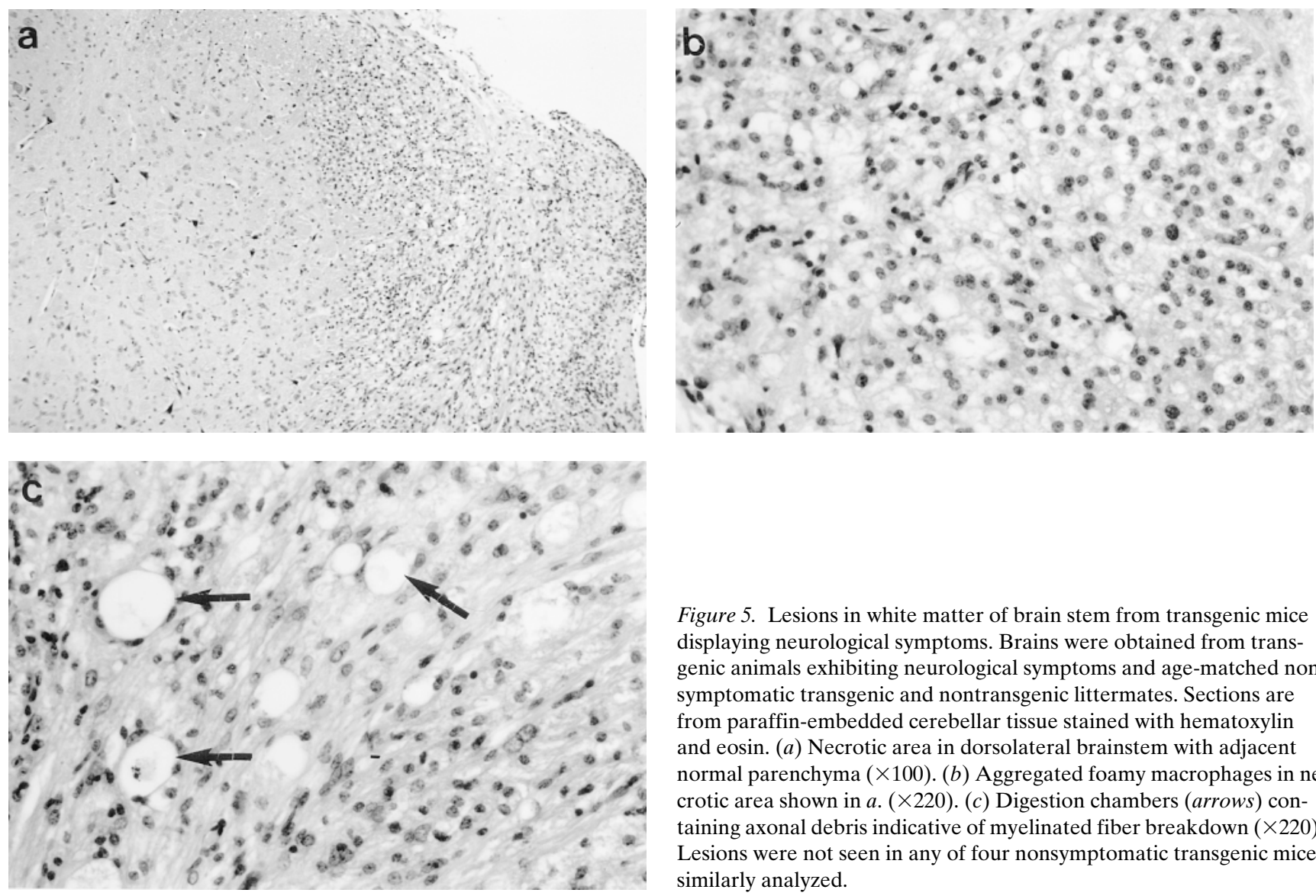

Figure 5. Lesions in white matter of brain stem from transgenic mice displaying neurological symptoms. Brains were obtained from transgenic animals exhibiting neurological symptoms and age-matched nonsymptomatic transgenic and nontransgenic littermates. Sections are from paraffin-embedded cerebellar tissue stained with hematoxylin and eosin. (a) Necrotic area in dorsolateral brainstem with adjacent normal parenchyma $(\times 100)$. (b) Aggregated foamy macrophages in necrotic area shown in $a .(\times 220)$. (c) Digestion chambers (arrows) containing axonal debris indicative of myelinated fiber breakdown $(\times 220)$. Lesions were not seen in any of four nonsymptomatic transgenic mice similarly analyzed. 
active form of the receptor, $\mathrm{h} \beta_{\mathrm{c}} \mathrm{FI} \Delta$ (21), under the control of the housekeeping promoter, $P G K-1$. Transgene mRNA is expressed in several tissues and the presence of $\mathrm{h} \beta_{\mathrm{c}} \mathrm{FI} \Delta$ protein was confirmed in transgenic spleen extracts. Furthermore, clonal assays confirmed activity of the mutant receptor in committed myeloid progenitors. Growth of a significant proportion of macrophage and granulocyte-macrophage progenitors from bone marrow and spleen of transgenic mice occurred in the absence of added cytokine, consistent with previous studies using retrovirally infected murine fetal liver progenitors (23). Expression of $\mathrm{h} \beta_{\mathrm{c}} \mathrm{FI} \Delta$ was below the limits of detectability using other techniques such as flow cytometry and we conclude that the phenotype of these transgenic mice is due to chronic low level production of $\mathrm{h} \beta_{\mathrm{c}} \mathrm{FI} \Delta$.

Peripheral blood analysis and tissue histology of transgenic mice revealed the presence of a trilineage hyperplasia in all transgenic animals. This disorder displayed complete penetrance in two independent lines of transgenic animals. Peripheral blood analysis indicated that all transgenic mice display mild to severe erythrocytosis. Bone marrow histology revealed granulocytic and megakaryocytic hyperplasia. Expansion of the granulocyte lineage in bone marrow was also evident in the differential counts and from a marked increase in staining for Gr-1, expression of which correlates with granulocyte differentiation and maturation (47). Most transgenic animals were also found to have pronounced splenomegaly, due to increased splenic erythropoiesis.

Despite the restricted effects of $\mathrm{h} \beta_{\mathrm{c}} \mathrm{FI} \Delta$ on primary progenitors derived from mouse fetal liver (23) there is a pronounced effect on the erythroid lineage, increased megakaryocyte numbers, and splenomegaly in this animal model. A possible explanation for this is that $\mathrm{h} \beta_{\mathrm{c}} \mathrm{FI} \Delta$ may be able to stimulate, or sensitize, multipotent progenitors via synergistic effects with other growth factors. Synergy of an activated cytokine receptor with other growth factor pathways has been demonstrated previously. Expression of an activated form of Epo-R (R129C) (48) in mice leads to increases in erythroid, megakaryocyte, and granulocyte-macrophage progenitors, while expression of the same form of Epo-R in primary fetal liver cells generates only factor-independent CFU-E (49). Expression of this form of Epo-R has been shown to impart a growth advantage on multipotent hematopoietic progenitors, in the presence of synergizing growth factors such as stem cell factor (SCF), resulting in amplification of several lineages in vivo (50). Clearly, transgenic bone marrow progenitors could respond differentially in the presence of SCF or other synergizing growth factors which act on early progenitors resulting in an expansion of several lineages. Further studies are underway to establish the properties of multipotent and multifactor requiring cells from the $\mathrm{h} \beta_{\mathrm{c}} \mathrm{FI} \Delta$ transgenic animals.

An alternative explanation is that erythropoiesis and megakaryopoiesis are stimulated via direct physical interactions between $\mathrm{h} \beta_{\mathrm{c}} \mathrm{FI} \Delta$, mEpo-R, and/or $\mathrm{m}$ thrombopoietin (Tpo)-R in committed progenitors. Consistent with a direct effect of $\mathrm{h} \beta_{\mathrm{c}^{-}}$ FI $\Delta$ on committed erythroid progenitors, we observed growth of CFU-E in spleen of transgenic animals in the absence of added Epo. It has been demonstrated recently that mEpo-R and $\mathrm{m} \beta_{\mathrm{c}}$ are constitutively associated in transfected $\mathrm{Ba} / \mathrm{F} 3$ cells (51). Epo has also been reported to induce tyrosine phosphorylation of $h \beta_{c}$ and $m \beta_{I L-3}$ in some cell lines $(24,52)$. In addition, thrombopoietin has been shown to induce tyrosine phosphorylation of $h \beta_{c}$ in the human erythroleukemia cell line, TF-1 suggesting a possible role for $h \beta_{c}$ in megakaryopoiesis (26). A more definitive demonstration of a functional role for $\beta_{c}$ in nonmyeloid lineages awaits the generation of animals lacking functional $\beta_{\mathrm{c}}$ and $\beta_{\mathrm{IL}-3}$. Animals deficient in either $\beta_{\mathrm{c}}$ or $\beta_{\mathrm{IL}-3}$ have not been shown to have impaired erythropoiesis or megakaryopoiesis $(53,54)$; however, these animals will have one of the $\beta$ subunits intact and this may still allow a functional interaction with Epo-R to occur. Nevertheless, the above studies raise the possibility that the presence of activated $h \beta_{c}$ in erythroid and megakaryocyte progenitors affects their sensitivity to growth factors via a direct interaction with Epo-R or Tpo-R.

The human myeloproliferative disorder polycythemia vera (PV) is characterized by splenomegaly and an increased production of erythrocytes, granulocytes, and platelets. Isoenzyme studies suggest that PV is a clonal disease of a multipotent stem cell (55). PV is gradual in onset and runs a chronic but slowly progressive course. The dominant feature of this disease is polycythemia and a concomitant elevated hemoglobin concentration and PCV (56). In bone marrow clonal assays, performed with serum containing medium, patients with PV characteristically exhibit CFU-E in the absence of added Epo (57). Molecular analysis of Epo-R in PV has failed to identify a disease-associated alteration $(58,59)$, thus it is unlikely that an acquired mutation of the Epo-R is responsible for PV. It is notable that PV hematopoietic progenitor cells are also hypersensitive to GM-CSF (60), IL-3 (61), and SCF (62). In addition, recent studies demonstrated that PV progenitor cells are 100-fold more sensitive to IGF-1 than normal cells (63) and indicate that the IGF-1 receptor on PV-derived cells displays increased basal phosphorylation (64).

The observation that PV progenitors appear to be hypersensitive to several growth factors suggests a defect in a shared receptor component or intracellular signaling pathway. Our work suggests that activating mutations in $\mathrm{h} \beta_{\mathrm{c}}$ can cause a dysregulation of hematopoiesis similar to that observed in PV. Founder transgenic mice, and transgenic animals from both stable transgenic lines, exhibit splenomegaly, amplification of erythroid, myeloid, and megakaryocyte lineages, and growth of CFU-E in the absence of added Epo. $h \beta_{c}$ is expressed in multipotent progenitors $(65,66)$ and it can be activated by several classes of mutation (19). Synergistic interactions of activated $h \beta_{c}$ with other growth factors in multipotent progenitors and direct interactions between $\beta c$, Epo-R, and Tpo-R may provide mechanisms for these activating mutations to influence erythropoiesis and megakaryopoiesis. Thus, we feel that the gene for $h \beta_{c}$ is a good candidate for mutations involved in PV. Given the extensive map now available for potential h $\beta \mathrm{c}$ activating mutations, which cluster mostly in the membraneproximal and transmembrane domains (19), it will be interesting to perform a comprehensive, fine-scale analysis of this region of the $h \beta_{c}$ gene in $\mathrm{PV}$ patients.

In addition to the hematological abnormalities, several founder transgenic mice displayed signs of neurological disease. Characteristically, the appearance of this disorder occurred with sudden onset, becoming progressively more severe over 1-2 wk, eventually leading to complete incapacitation. The neurological disorder has been maintained in two independent transgenic lines, occurring sporadically and with varying age of onset. The neurological symptoms observed in affected mice correlated with the presence of necrotic lesions in the pons and cerebellar peduncles. Cerebellum and brain stem are major centers controlling motor function (67); thus, these 
lesions are the probable cause of motor disease in the $\mathrm{h} \beta_{\mathrm{c}} \mathrm{FI} \Delta$ transgenic mice.

We speculate that these lesions may be initiated as a result of $\mathrm{h} \beta_{\mathrm{c}} \mathrm{FI} \Delta$ activity in cells resident in brain stem. Macrophages resident in white matter (microglia) are candidates for initiating the tissue damage given that they are derived from the myeloid lineage $(68)$, that they normally respond to IL-3 $(69,70)$, and that they have been demonstrated to express $\mathrm{h} \beta_{\mathrm{c}}(71)$. Activated macrophages secrete soluble factors that include cytokines, serine proteases, prostaglandins, and reactive oxygen species that may be responsible for the initial tissue injury (72). The sporadic nature of the disease and the fact that lesions are restricted to the pons and cerebellar region of the brain imply that further priming events are required in $\mathrm{h} \beta_{\mathrm{c}} \mathrm{FI} \Delta$ transgenic mice to initiate these lesions. We suggest that once a threshold number of macrophages are generated by local proliferation there may be further activation of resident macrophages and/ or perivascular endothelium which may, in turn, provide signals for recruitment and extravasation of peripheral macrophages. It is curious that there is a lack of any similar neurological disorder in transgenic animals ubiquitously expressing hGM-CSF receptor $\alpha$ and $\beta$ subunits, when administered hGM-CSF over a $1 \mathrm{wk}$ period (73). Neurological disease in the $\mathrm{h} \beta_{\mathrm{c}} \mathrm{FI} \Delta$ transgenic mice is likely to be a result of chronic exposure to a GM-CSF or IL-3 signal and may take $>1$ wk to develop to the point where mice display neurological symptoms. Alternatively, in the GM-CSF receptor transgenic animals, the administered GM-CSF cannot cross the blood-brain barrier and is not able to stimulate cells resident in the cerebellum.

In conclusion, transgenic mice with chronic low level expression of an activated $\mathrm{h} \beta_{\mathrm{c}}$ mutant develop a myeloproliferative disorder characterized by granulocytic, megakaryocytic, and erythroid hyperplasia. The pathophysiology of this disorder shows similarities to the human condition PV, suggesting that the $\mathrm{h} \beta_{\mathrm{c}} \mathrm{FI} \Delta$ mouse may be a useful animal model for this disorder. Furthermore, lesions in $h \beta_{c}$ may be causal in the pathogenesis of PV, possibly through a mechanism involving synergy with other growth factors or interactions with other cytokine receptors. In addition these mice develop a progressive neurological disorder as a result of macrophage accumulation in response to necrotic lesions in the pons and cerebellar peduncles. While the basis for this lesion is unknown, it suggests that chronic activation of the GM-CSF/IL-3 receptor in cell types resident in brain stem can initiate tissue damage and may underlie degenerative disease in this tissue.

\section{Acknowledgments}

We are very grateful to Dr. Ivan Bertoncello and Dr. Tim Hughes for valuable discussions. We also thank Brigit Mills and Loren Matthews for maintenance of transgenic mouse colonies, and Jenny Langman for tissue sectioning and staining. Antibodies for cell surface typing were kindly provided by Dr. A. Strasser (Walter and Eliza Hall Institute) and Dr. I. Bertoncello (Peter MacCallum Cancer Research Institute, Melbourne, Victoria, Australia).

This work was supported by grants from the National Health and Medical Research Council of Australia and the Anti-Cancer Foundation of South Australia. R.J. D'Andrea is supported by an HM Lloyd Senior Research Fellowship in Oncology from the University of Adelaide.

\section{References}

1. Bagley, C.J., J.M. Woodcock, F.C. Stomski, and A.F. Lopez. 1997. The structural and functional basis of cytokine receptor activation: lessons from the common $\beta$ subunit of the granulocyte-macrophage colony-stimulating factor, interleukin-3 (IL-3) and IL-5 receptors. Blood. 89:1471-1482.

2. Miyajima, A., A.L. Mui, T. Ogorochi, and K. Sakamaki. 1993. Receptors for granulocyte-macrophage colony-stimulating factor, interleukin-3, and interleukin-5. Blood. 82:1960-1974.

3. Miyajima, A., T. Kiamura, N. Harada, T. Yokota, and K. Arai. 1992. Cytokine receptors and signal transduction. Ann. Rev. Immunol. 10:295-331.

4. Arai, K., F. Lee, A. Miyajima, S. Miyatake, N. Arai, and T. Yokota. 1990 Cytokines: coordinators of immune and inflammatory responses. Annu. Rev. Biochem. 59:783-836.

5. Schrader, J.W. 1986. The pan specific hemopoietin of activated T lymphocytes (interleukin-3). Ann. Rev. Immunol. 4:205-230.

6. Frendl, G., and D.I. Beller. 1990. Regulation of macrophage activation by IL-3. J. Immunol. 144:3392-3399.

7. Burgess, A.W., J. Camakaris, and D. Metcalf. 1977. Purification and properties of colony-stimulating factor from mouse lung conditioned medium. J. Biol. Chem. 252:1998-2006.

8. Metcalf, D., G.R. Burgess, G.R. Johnson, N.A. Nicola, E.C. Nice, J. DeLamarter, G.R. Thatcher, and J. Mermod. 1986. In vitro actions on hemopoietic cells of recombinant murine GM-CSF purified after production in $E$. coli comparison with purified native GM-CSF. J. Cell. Physiol. 128:421.

9. Burke, F., M.S. Naylor, B. Davies, and F. Balkwill. 1993. The cytokine wall chart. Immunol. Today. 14:165-169.

10. Vadas, M.A., and A.F. Lopez. 1984. Regulation of granulocyte function by colony stimulating factors. Lymphokine Res. 3:45-50.

11. Lopez, A.F., C.J. Sanderson, J.R. Gamble, H.D. Campbell, I.G. Young, and M.A. Vadas. 1988. Recombinant human interleukin 5 is a selective activator of human eosinophil function. J. Exp. Med. 167:219-224.

12. Lopez, A.F., L.B. To, Y. Yang, J.R. Gamble, M.F. Shannon, G.F. Burns, P.G. Dyson, C.A. Juttner, S. Clark, and M.A. Vadas. 1987. Stimulation of proliferation, differentiation, and function of human cells by primate interleukin-3. Proc. Natl. Acad. Sci. USA. 84:2761-2765.

13. Sanderson, C.J. 1992. Interleukin-5, eosinophils and disease. Blood. 79: 3101-3109.

14. Takagi, M., T. Hara, M. Ichihara, K. Takatsu, and A. Miyajima. 1995. Multi-colony stimulating activity of interleukin-5 (IL-5) on hematopoietic progenitors from transgenic mice that express IL-5 receptor $\alpha$ subunit constitutively. J. Exp. Med. 181:889-899.

15. Khew-Goodall, Y., C.M. Butcher, M.S. Litwin, S. Newlands, E.I. Korpelainen, L.M. Noack, M. Berndt, A.F. Lopez, J.R. Gamble, and M.A. Vadas 1996. Chronic expression of P-selectin on endothelial cells stimulated by the T-cell cytokine, interleukin-3. Blood. 87:1432-1438.

16. Goodall, G.J., C.J. Bagley, M.A. Vadas, and A.F. Lopez. 1993. A model for the interaction of the GM-CSF, IL-3 and IL-5 receptors with their ligands. Growth Factors. 8:87-97.

17. Mui, A.L., and A. Miyajima. 1994. Cytokine receptors and signal transduction. Prog. Growth Factor. Res. 5:15-35.

18. Wells, J.A., and A.M. de Vos. 1996. Hematopoietic receptor complexes. Annu. Rev. Biochem. 65:609-634.

19. Gonda, T.J., and R.J. D'Andrea. 1997. Activating mutations in cytokine receptors: implications for receptor function and role in disease. Blood. 89:355369.

20. Jenkins, B.J., R.J. D’Andrea, and T.J. Gonda. 1995. Activating point mutations in the common $\beta$ subunit of the human GM-CSF, IL-3 and IL-5 receptors suggest the involvement of $\beta$ subunit dimerization and cell typespecific molecules in signalling. EMBO (Eur. Mol. Biol. Organ.) J. 14:42764287.

21. D'Andrea, R., J. Rayner, P. Moretti, A. Lopez, G.J. Goodall, T.J. Gonda, and M.A. Vadas. 1994. A mutation of the common receptor subunit for interleukin-3 (IL-3), granulocyte-macrophage colony-stimulating factor, and IL-5 that leads to ligand independence and tumorigenicity. Blood. 83:28022808.

22. D'Andrea, R.J., S.C. Barry, P.A.B. Moretti, K. Jones, S. Ellis, M.A. Vadas, and G.J. Goodall. 1996. Extracellular truncations of $h \beta_{c}$, the common signaling subunit for interleukin-3 (IL-3), granulocyte-macrophage colony-stimulating factor (GM-CSF) and IL-5, lead to ligand-independent activation. Blood. 87:2641-2648.

23. McCormack, M.P., and T.J. Gonda. 1997. Expression of activated mutants of the human interleukin-3/interleukin-5/granulocyte-macrophage colonystimulating factor receptor common $\beta$ subunit in primary hematopoietic cells induces factor-independent proliferation and differentiation. Blood. 90:14711481.

24. Hanazono, Y., K. Sasaki, H. Nitta, Y. Yazaki, and H. Hirai. 1995. Erythropoietin induces tyrosine phosphorylation of the beta chain of the GM-CSF receptor. Biochem. Biophys. Res. Commun. 208:1060-1066.

25. Pan, C.X., R. Fukunaga, S. Yonehara, and S. Nagata. 1993. Unidirectional cross-phosphorylation between the granulocyte colony-stimulating factor and interleukin-3 receptors. J. Biol. Chem. 268:25818-25825.

26. Ooi, J., A. Tojo, S. Asano, Y. Sato, and Y. Oka. 1998. Thrombopoietin induces tyrosine phosphorylation of a common beta subunit of GM-CSF receptor and its association with Stat5 in TF-1/TPO cells. Biochem. Biophys. Res. Commun. 246:132-136.

27. Feldmann, M., F.M. Brennan, and R.N. Maini. 1995. Role of cytokines 
in autoimmune diseases. In Human Cytokines: Their Role in Disease and Therapy. B. Bharat, B.B. Aggarwal, and R.K. Puri, editors. Blackwell Science, Cambridge, MA. 185-194.

28. Benveniste, E.N. 1995. Role of cytokines in multiple sclerosis, autoimmune encephalitis, and other neurological disorders. In Human Cytokines: Their Role in Disease and Therapy. B. Bharat, B.B. Aggarwal, and R.K. Puri, editors. Blackwell Science, Cambridge, MA. 195-216.

29. Unemori, E.N., and E.P. Amento. 1995. Role of cytokines in rheumatoid arthritis. In Human Cytokines: Their Role in Disease and Therapy. B. Bharat, B.B. Aggarwal, and R.K. Puri, editors. Blackwell Science, Cambridge, MA. 217-236.

30. Waller, S.J., J.M. Funkhouser, K. Chooi, and D. Murphy. 1995. Genomic and expression analysis of transgenic animals. In DNA Cloning. D.M. Glover and B.D. Hames, editors. Oxford University Press, New York. 231-262.

31. Armitage, P., and G. Berry. 1987. Statistical Methods in Medical Research. Blackwell Scientific Publications, Oxford.

32. Metcalf, D. 1984. Clonal Culture of Hemopoietic Cells: Techniques and Applications. Elsevier, Amsterdam.

33. Holmes, K.L., W.Y. Langdon, T.N. Fredricksen, R.L. Cofman, P.M. Hoffman, J.W. Hartley, and H.C.I. Morse. 1986. Analysis of neoplasms induced by Cas-Br-M MuLV extracts. J. Immunol. 137:679-689.

34. Coffman, B. 1982. Surface antigen expression and immunoglobulin rearrangement during mouse pre-B cell development. Immunol. Rev. 69:5-23.

35. Ballas, Z.K., and W. Rasmussen. 1993. Lymphokine-activated killer cells. VII. IL-4 induces an NK1.1+CD8 alpha+beta- TCR-alpha beta B220+ lymphokine-activated killer subset. J. Immunol. 150:17-30.

36. Ogawa, M., Y. Matsuzaki, S. Nishikawa, S. Hayashi, T. Kunisada, T. Sudo, T. Kina, H. Nakauchi, and S. Nishikawa. 1991. Expression and function of $c$-kit in hemopoietic cells. J. Exp. Med. 174:63-71.

37. Ikuta, K., T. Kina, I. MacNiel, N. Uchida, B. Peault, Y. Chien, and I.L. Weissman. 1990. A developmental switch in thymic lymphocyte maturation potential occurs at the level of hematopoietic stem cells. Cell. 62:863-874.

38. Ledbetter, J.A., and L.A. Herzenberg. 1979. Xenogeneic monoclonal antibodies to mouse lymphoid differentiation antigens. Immunol. Rev. 47:63.

39. Woodcock, J.M., C.J. Bagley, B. Zacharakis, and A.F. Lopez. 1996. A single tyrosine residue in the membrane proximal domain of the GM-CSF, IL-3 and IL-5 receptor common $\beta$ chain is necessary and sufficient for high affinity binding and signaling by all three ligands. J. Biol. Chem. 271:25999-26006.

40. Stomski, F., Q. Sun, C. Bagley, J. Woodcock, G. Goodall, R. Andrews, M. Berndt, and A. Lopez. 1996. Human interleukin-3 (IL-3) induces disulfidelinked receptor $\alpha$ and $\beta$ chain heterodimerization which is required for receptor activation but not high affinity binding. Mol. Cell. Biol. 16:3035-3046.

41. McBurney, M.W., L.C. Sutherland, C.N. Adra, B. Leclair, M.A. Rudnicki, and K. Jardine. 1991. The mouse $P G K-1$ gene promoter contains an upstream activator sequence. Nucl. Acids Res. 19:5755-5761.

42. Metcalf, D., C.G. Begley, G.R. Johnson, N.A. Nicola, A.F. Lopez, and D.J. Williamson. 1986. Effects of purified bacterially synthesized murine multiCSF (IL-3) on hematopoiesis in normal adult mice. Blood. 68:46-54

43. Metcalf, D., C.G. Begley, D.J. Williamson, E.C. Nice, J. De Lamarter, J.J. Mermod, D. Thatcher, and A. Schmidt. 1987. Hemopoietic responses in mice injected with purified recombinant murine GM-CSF. Exp. Hematol. 15:110.

44. Yasuda, Y., I. Nishijima, S. Watanabe, K. Arai, A. Zlotnik, and T.A. Moore. 1997. Human granulocyte-macrophage colony-stimulating factor (hGM-CSF) induces inhibition of intrathymic T-cell development in hGM-CSF receptor transgenic mice. Blood. 89:1349-1356.

45. Blumbergs, P.C., G. Scott, J. Manavis, H. Wainwright, D.A. Simpson, and A.J. McLean. 1994. Staining of amyloid precursor protein to study axonal damage in mild head injury. Lancet. 344:1055-1056.

46. Chiang, C., H.C. Powell, L.H. Gold, A. Samimi, and I.L. Campbell. 1996. Macrophage/microglial-mediated primary demyelination and motor disease induced by the central nervous system production of interleukin-3 in transgenic mice. J. Clin. Invest. 97:1512-1524.

47. Hestdal, K., F.W. Ruscetti, J.N. Ihle, S.E.W. Jacobsen, C.M. Dubois, W.C. Kopp, D.L. Longo, and J.R. Keller. 1991. Characterisation and regulation of RB6-8C5 antigen expression on murine bone marrow cells. J. Immunol. 147: $22-28$

48. Longmore, G.D., and H.F. Lodish. 1991. An activating mutation in the murine erythropoietin receptor induces erythroleukemia in mice: a cytokine receptor superfamily oncogene. Cell. 67:1089-1102.

49. Longmore, G.D., P. Pharr, D. Neumann, and H.F. Lodish. 1993. Both megakaryocytopoiesis and erythropoiesis are induced in mice infected with a retrovirus expressing an oncogenic erythropoietin receptor. Blood. 82:23862395.

50. Pharr, P.N., D. Hankins, A. Hofbauer, H.F. Lodish, and G.D. Longmore. 1993. Expression of a constitutively active erythropoietin receptor in primary hematopoietic progenitors abrogates erythropoietin dependence and enhances erythroid colony-forming unit, erythroid burst-forming unit, and granulocyte/macrophage progenitor growth. Proc. Natl. Acad. Sci. USA. 90: 938-942.

51. Jubinsky, P.T., O.I. Krijanovski, D.G. Nathan, J. Tavernier, and C.A. Sieff. 1997. The $\beta$ chain of the interleukin-3 receptor functionally associates with the erythropoietin receptor. Blood. 90:1867-1873.

52. Chin, H., H. Wakao, A. Miyajima, R. Kamiyama, N. Miyasaka, and O. Miura. 1997. Erythropoietin induces tyrosine phosphorylation of the interleukin-3 receptor $\beta$ subunit $\left(\beta_{\mathrm{IL}-3}\right)$ and recruitment of Stat5 to possible Stat5-docking sites in $\beta_{\mathrm{IL}-3}$. Blood. 89:4327-4336.

53. Nishinakamura, R., N. Nakayama, Y. Hirabayashi, T. Inoue, D. Aud, T. McNeil, S. Azuma, S. Yoshida, Y. Toyoda, K. Arai, et al. 1995. Mice deficient for the IL-3/GM-CSF/IL-5 $\beta$ c receptor exhibit lung pathology and impaired immune response, while $\beta_{\mathrm{IL}-3}$ receptor-deficient mice are normal. Immunity. 2 211-222.

54. Stanley, E., G.J. Lieschke, D. Grail, D. Metcalf, G. Hodgson, J.A. Gall, D.W. Maher, J. Cebon, V. Sinickas, and A.R. Dunn. 1994. Granulocyte/macrophage colony-stimulating factor-deficient mice show no major perturbation of hematopoiesis but develop a characteristic pulmonary pathology. Proc. Natl. Acad. Sci. USA. 91:5592-5596.

55. Adamson, J.W., P.J. Fialkow, S. Murphy, J.F. Prchal, and L. Steinmann. 1976. Polycythemia vera: stem-cell and probable clonal origin of the disease. $N$. Engl. J. Med. 295:913-916.

56. Adamson, J.W., and P.J. Fialkow. 1978. The pathogenesis of myeloproliferative syndromes. Br. J. Haematol. 38:299-303.

57. Weinberg, R.S., A. Worsley, H.S. Gilbert, J. Cuttner, P.D. Berk, and B.P. Alter. 1989. Comparison of erythroid progenitor cell growth in vitro in polycythemia vera and chronic myelogenous leukemia: only polycythemia vera has endogenous colonies. Leuk. Res. 13:331-338.

58. Emanuel, P.D., C.J. Eaves, V.C. Broudy, T. Papayannopoulou, M.R. Moore, A.D. D'Andrea, J.F. Prchal, A.C. Eaves, and J.T. Prchal. 1992. Familial and congenital polycythemia in three unrelated families. Blood. 79:3019-3030.

59. Hess, G., P. Rose, H. Gamm, S. Papadileris, C. Huber, and B. Seliger 1994. Molecular analysis of the erythropoietin receptor system in patients with polycythaemia vera. Br. J. Haematol. 88:794-802.

60. Dai, C.H., S.B. Krantz, E.N. Dessypris, R.T. Means, Jr., S.T. Horn, and H.S. Gilbert. 1992. Polycythemia vera. II. Hypersensitivity of bone marrow erythroid, granulocyte-macrophage, and megakaryocyte progenitor cells to interleukin-3 and granulocyte-macrophage colony-stimulating factor. Blood. 80: 891-899.

61. Dai, C.H., S.B. Krantz, R.T. Means, Jr., S.T. Horn, and H.S. Gilbert. 1991. Polycythemia vera blood burst-forming units-erythroid are hypersensitive to interleukin-3. J. Clin. Invest. 87:391-396.

62. Dai, C.H., S.B. Krantz, W.F. Green, and H.S. Gilbert. 1994. Polycythaemia vera. III. Burst-forming units-erythroid (BFU-E) response to stem cell factor and c-kit receptor expression. Br. J. Haematol. 86:12-21.

63. Correa, P.N., D. Eskinazi, and A.A. Axelrad. 1994. Circulating erythroid progenitors in polycythemia vera are hypersensitive to insulin-like growth factor-1 in vitro: studies in an improved serum-free medium. Blood. 83:99-112.

64. Mirza, A.M., P.N. Correa, and A.A. Axelrad. 1995. Increased basal and induced tyrosine phosphorylation of the insulin-like growth factor I receptor beta subunit in circulating mononuclear cells of patients with polycythemia vera. Blood. 86:877-882.

65. Testa, U., E. Pelosi, M. Gabbianelli, C. Fossati, S. Campisi, G. Isacchi, and C. Peschle. 1993. Cascade transactivation of growth factor receptors in early human hematopoiesis. Blood. 81:1442-1456.

66. Sato, N., C. Caux, T. Kitamura, Y. Watanabe, K. Arai, J. Banchereau, and A. Miyajima. 1993. Expression and factor-dependent modulation of the in terleukin-3 receptor subunits on human hematopoietic cells. Blood. 82:752-761.

67. Thack, W.T., H.P. Goodkin, and J.G. Keating. 1992. The cerebellum and the adaptive coordination of movement. Ann. Rev. Neurosci. 62:403-442.

68. Ling, E., and W. Wong. 1993. The origin and nature of ramified and amoeboid microglia: a historical review and current concepts. Glia. 7:9-18.

69. Frendl, G. 1992. Interleukin-3: from colony stimulating factor to pluripotent immunoregulatory cytokine. J. Immunol. 14:421-430.

70. Gebicke-Haerter, P.J., K. Appel, G.D. Taylor, A. Schobert, I.N. Rich, H. Northoff, and M. Berger. 1994. Rat microglial interleukin-3. J. Neuroimmunol. 50:203-214.

71. Appel, K., M. Buttini, A. Sauter, and P.J. Gebicke-Haerter. 1995. Cloning of rat interleukin-3 receptor beta-subunit from cultured microglia and its mRNA expression in vivo. J. Neurosci. 15:5800-5809.

72. Banati, R.B., J. Gehrmann, P. Schubert, and G.W. Kreutzberg. 1993. Cytotoxicity of microglia. Glia. 7:111-118.

73. Nishijima, I., T. Nakahata, S. Watanabe, K. Tsuji, I. Tanaka, Y. Hirabayashi, T. Inoue, and K. Arai. 1997. Hematopoietic and lymphopoietic responses in human granulocyte-macrophage colony-stimulating factor (GM-CSF) receptor transgenic mice injected with human GM-CSF. Blood. 90:1031-1038. 